TULIĆ, A., SEFEROVIĆ, N., Dokazivanje umišljaja kod krivičnih djela počinjenih od strane službene ili odgovorne osobe Zbornik radova Pravnog fakulteta Sveučilišta u Mostaru, br. XXVII., 2019., str. 138. - 159.

Mr. sc. Adnan TULIĆ

UDK: 343.369

Kantonalno tužilaštvo Unsko-sanskog kantona

Stručni rad

adnan.tulic@pravosudje.ba

Primljen: 29. kolovoza 2018.

Prihvaćen: 3. travnja 2019.

Dipl. iur. Nedim SEFEROVIĆ

Kantonalno tužilaštvo Unsko-sanskog kantona

nedim.seferovic@pravosudje.ba

\title{
DOKAZIVANJE UMIŠLJAJA KOD KRIVIČNIH DJELA POČINJENIH OD STRANE SLUŽBENE ILI ODGOVORNE OSOBE
}

\begin{abstract}
Sažetak: Razumijevanje i dokazivanje psihičkog odnosa počinitelja krivičnih djela, kod kojih se kao počinitelj javlja službena ili odgovorna osoba, prema tim djelima predstavlja, prvenstveno za tužilaštva, vjerojatno najveći izazov. Umišljaj, kao fokalna tačka krivičnopravnog sistema, u realnosti u kojoj krivični progon počinilaca ove vrste krivičnih djela nesporno predstavlja zadatak od izuzetnog društvenog $i$ kriminalnopolitičkog značaja, jeste institut koji se izdvaja po svom značaju i čijem dokazivanju je potrebno posvetiti značajnu pažnju. Od presudne je važnosti percipirati ovaj institut na način koji je utemeljen u krivičnopravnoj doktrini, kako bi se izbjegli bilo kakvi oblici arbitrarnosti procesnih subjekata u danom pogledu, i kako bi se pravilnim razumijevanjem ovog oblika krivnje u toku postupka u potpunosti realizirala svrha krivičnopravnog progona i sankcioniranja. U tom smislu, potrebno je istaknuti neke od dilema koje se javljaju prilikom ocjene postojanja umišljaja na strani počinioca navedenih krivičnih djela. U ovom radu, autori su ponudili doktrinarni pregled suštinskog poimanja umišljaja u okvirima domaće i strane krivičnopravne dogmatike, prezentirajući opća zapažanja o ovom institutu, njegov pojam i elemente, nastojeći naglasiti potrebu za distinkcijom između umišljaja, zablude o supsumpciji, svijesti o protupravnosti, stvarne i pravne zablude, uz praktične primjere iz sudske prakse koji govore u prilog argumentima iznesenim u radu. Pored navedenog, dat je osvrt na krivnju kao element krivičnog djela Zloupotrebe položaja ili ovlaštenja kao genusnog djela pravih službeničkih krivičnih djela, a zatim su prezentirani najčešći problemi u dokazivanju umišljaja s aspekta tužilaštva, uz nastojanje autora da na temelju vlastitog viđenja potencijalnih načina prevazilaženja tih problema ponude rješenja prisutnih nedoumica.
\end{abstract}

Ključne riječi: krivično djelo, umišljaj, dolus, krivnja, službena osoba, odgovorna osoba 


\section{Uvod}

Problematika dokazivanja umišljaja u predmetima u kojima se počinitelji terete za izvršenje krivičnih djela koja konstituiraju katalog pravih službeničkih krivičnih djela (vlastoručna službenička krivična djela, delicta propria) ${ }^{1}$, kao temelj za aktualiziranje diskusije o granicama i načinu shvatanja umišljaja, pred sudionike u postupku krivične istrage i krivičnog postupka, ali i teoretičare krivičnog prava, postavlja pitanje reaktualizacije i redefiniranja teorijskih shvatanja i praktičnih implikacija ove materije. Iako pitanje ostvarivanja subjektivnog elementa na strani počinioca nije problematično samo kod vlastoručnih, već i kod svih ostalih krivičnih djela, specifičnost položaja subjekata, odnosno službenih ili odgovornih osoba, kod ovih krivičnih djela postojanje umišljaja veoma često postavlja kao najproblematičniji element pri dokazivanju izvršenja tih djela. Svojstvo počinitelja ovih krivičnih djela za potrebe ovog rada sagledano je kroz prizmu definicija koju nudi Krivični zakon Federacije BiH (Službene novine FBiH, br. 36/03, 37/03, 21/04, 69/04, 18/05, 42/10, 42/11, 59/14, 76/14, 46/16, dalje u tekstu: $\mathrm{KZ} \mathrm{FBiH).}$

Shodno odredbama člana 2. stav 3. i 6. KZ FBiH, službena osoba je izabrani ili imenovani službenik ili druga službena osoba u organima zakonodavne, izvršne i sudske vlasti i u drugim organima uprave i službama za upravu Federacije, kantona, gradova i općina koje obavljaju određene upravne, stručne i druge poslove u okviru prava i dužnosti vlasti koja ih je osnovala; osoba koja stalno ili povremeno vrši službenu dužnost u navedenim organima i tijelima; ovlašćena osoba u privrednom društvu ili u drugoj pravnoj osobi kojoj je zakonom ili drugim propisom donesenim na osnovu zakona povjereno obavljanje javnih ovlašćenja, a koja u okviru tih ovlasti obavlja određenu funkcija; te druga osoba koja obavlja određenu službenu funkcija na osnovu ovlašćenja iz zakona ili drugog propisa donesenog na osnovu zakona. Odgovorna osoba je osoba u privrednom društvu ili u drugoj pravnoj osobi kojoj je s obzirom na njenu dužnost ili na osnovu posebne ovlasti povjeren određeni krug poslova koji se odnose na primjenu zakona ili propisa donesenih na osnovu zakona, ili općeg akta privrednog društva ili druge pravne osobe u upravljanju i rukovanju imovinom, ili se odnose na ruko-

Pod ovim pojmom u najužem smislu, za potrebe ovog rada podrazumijevamo krivična djela protiv privrede, poslovanja i sigurnosti platnog prometa; krivična djela iz oblasti poreza, te krivična djela podmićivanja i krivična djela protiv službene i druge odgovorne funkcije, normirana u glavama XXII, XXIII i XXXI Krivičnog zakona FBiH, ali i druga krivična djela koja su određena posebnim svojstvom počinitelja kao službene ili odgovorne osobe. Navedena krivična djela uz neznatna odstupanja propisana su analogno i u krivičnim zakonima BiH, Republike Srpske i Brčko Distrikta BiH. Korištenje termina vlastoručna službenička krivična djela u ovom radu podrazumijeva sva ona krivična djela kod kojih se kao počinitelji javljaju službene odnosno odgovorne osobe. 
vođenje proizvodnjom ili nekom drugom privrednom djelatnošću ili na nadzor nad njima. Odgovornom osobom smatra se i službena osoba u smislu stava 3. ovog člana kad su u pitanju radnje čijim je počiniteljem označena odgovorna osoba, a nisu propisane kao krivično djelo odredbama glave o krivičnim djelima protiv službene i druge odgovorne funkcije ili odredbama o krivičnim djelima čiji je počinitelj službena osoba propisanima u nekoj drugoj glavi ovog zakona ili drugim zakonom Federacije ili kantona.

U okviru naprijed navedene problematike, pred tužilaštva je postavljen imperativan zahtjev da dolus ex indiciis perspiculis probari convenit (umišljaj treba dokazati potpuno jasnim dokazima). U nastojanjima da odgovore na ovaj zahtjev, u krivičnom postupku tužilaštva se često susreću s neujednačenom praksom i stavovima u pogledu standarda dokazivanja, traženog kvaliteta, kvantiteta i vrste dokaza, načina dokazivanja i u konačnici i u pogledu shvatanja umišljaja kao jednog od centralnih instituta općeg dijela krivičnog prava. Upravo zbog svoje važnosti, koju neki autori prepoznaju pridajući umišljaju kvalitet „fokalne tačke krivičnopravnog sistema “ ${ }^{\text {" }}$, u svrhu osiguranja potpune pravne sigurnosti uz uvažavanje kriminalno-političke realnosti današnjice u kojoj krivični progon počinitelja ovakve vrste krivičnih djela nesporno zauzima izuzetan značaj, potrebno je problematiku dokazivanja umišljaja svesti u okvire koji će garantirati potpuno ostvarenje svrhe krivičnopravnog progona i sankcionisanja, uz onemogućavanje bilo kakvog oblika arbitrarnosti procesnih subjekata u datom pogledu.

Smatrajući da je od značaja pred stručnu javnost iznijeti određena zapažanja u pogledu dokazivanja umišljaja kao zahtijevanog oblika krivnje promatranog kao pretpostavke za krivičnu odgovornost i kažnjivost počinitelja krivičnog djela, u početnom dijelu ovog rada predstavljeno je pojmovno određenje umišljaja uz napomene o konceptualnim, teorijskim načelima ovog pojma, osvrt na intelektualnu i voluntarističku komponentu umišljaja, odnos svijesti počinitelja o krivičnom djelu i zablude o supsumciji, svijest o protupravnosti djela kao eventualne negacije umišljaja uz pokušaj doktrinarnog razgraničenja zablude o biću djela i zablude o protupravnosti, dok su u preostalom dijelu rada predstavljeni praktični slučajevi koji mogu poslužiti kao ogledni iskustveni primjeri koji pokazuju s kakvim se izazovima susreću tužioci, ali i sudovi postupajući u predmetima u kojima se počinitelje tereti za počinjenje određenog krivičnog djela koje po svojim značajkama odgovara pravim službeničkim krivičnim djelima, uz nastojanje autorā da kroz vlastito viđenje ovog problema ponude eventualno polazište za diskusiju i mogućnost za prevazilaženje evidentno prisutnih dvojbi u rješavanju predstavljene problematike.

\footnotetext{
2 Bung, J., Wissen und Wollen im Strafrecht. Zur Theorie und Dogmatik des subjektives Tatbestands, Vittorio Klostermann Verlag, Frankfurt am Main, 2009., str. 5.
} 


\section{Umišljaj kao oblik krivnje}

\subsection{Opća razmatranja o krivnji}

Fundamentalna pozicija krivičnopravne dogmatike podrazumijeva zahtjev za utvrđivanjem određenog subjektivnog odnosa počinitelja prema svojem djelu kako bi pravni sistem uopće mogao, uz pretpostavku postojanja voljno preuzete radnje u cilju prouzrokovanja zabranjene posljedice, počinitelju uputiti prijekor odnosno sankciju. Krivnja je stoga kao subjektivni uvjet, uz postojanje slobodno poduzetog (dovršenog ili pokušanog) objektivnog čina, temelj za odgovornost počinioca krivičnog djela. Krivnja je subjektivni odnos počinitelja prema djelu zbog kojeg mu se može uputiti prijekor. ${ }^{3}$ Naš zakonodavac članom 4. (a) KZ $\mathrm{FBiH}$ prihvata načelo krivnje izražavajući ga odredbom da niko ne može biti kažnjen niti se prema njemu mogu izreći druge krivičnopravne sankcije, ako nije kriv za počinjeno krivično djelo. Ovakvo zakonsko rješenje svoj izraz crpi iz fundamentalne postavke krivičnog prava izražene kroz princip nulla poena sine culpa - nema kazne bez krivnje.

Navedeni princip eksplicira se dalje kroz zakonske odredbe koje propisuju da se krivnja može pripisati samo onom počinitelju krivičnog djela koji je tempore criminis bio uračunljiv i pri tome postupao $s$ umišljajem, odnosno onom počinitelju koji je postupao iz nehata ako zakon izričito predviđa krivnju i za postupanje iz nehata $^{4}$. Krivnja obuhvata kako radnju, tako i posljedicu i uzročni odnos, dakle krivično djelo u cjelini. Ona se kao psihički odnos izražava u postojanju svijesti o radnji, posljedici, uzročnom odnosu između radnje i nastupjele posljedice te svijesti o svim okolnostima učinjenog krivičnog djela, kao i u postojanju htijenja ili pristajanja na proizvedenu posljedicu. ${ }^{5}$ Upravo iz razloga tražene kongruentnosti krivnje i ukupnog neprava, kod koje krivnja mora obuhvatiti sve elemente počinjenog neprava, ovaj subjektivni, psihički odnos prema krivičnom djelu kod počinitelja mora postojati u vrijeme postupanja koje ulazi u sastav radnje izvršenja krivičnog djela.

Promatrana kao psihički odnos počinitelja prema svom djelu, krivnja se eksplicira kroz sadržaj svijesti i volje počinitelja krivičnog djela. Utvrđivanje svijesti i volje u svakom konkretnom slučaju znači ustanovljavanje obima i sadržine pred-

\footnotetext{
3 Novoselec, P., Opći dio kaznenog prava, Pravni fakultet Sveučilišta u Zagrebu, Zagreb, 2009., str. 229.

4 Član 35. Krivičnog zakona Federacije BiH (Službene novine FBiH, br. 36/03, 37/03, 21/04, 69/04, 18/05, 42/10, 42/11, 59/14, 76/14, 46/16).

5 Petrović, B., Jovašević D., Krivično/kazneno pravo Bosne i Hercegovine, opći dio, Pravni fakultet Univerziteta u Sarajevu, Sarajevo, 2005., str. 215.
} 
stave o djelu i intenziteta voljnog odnosa prema posljedici (stepena krivnje). ${ }^{6} \mathrm{Ra}-$ zlikovanje između krivnje i uračunljivosti zasniva se na tome što se kod procjene uračunljivosti utvrđuje da li je počinitelj uopće mogao da shvati značaj svog djela i da li je uopće mogao upravljati svojim postupcima u vrijeme počinjenja krivičnog djela, dok se kod utvrđivanja krivnje utvrđuje da li je počinitelj bio svjestan svog djela i da li je to djelo htio ili se s njim na drugi način suglasio. Uračunljivost je, prema tome, sposobnost za krivnju, a sama krivnja je konkretizacija te sposobnosti. ${ }^{7}$

Vladajuće je mišljenje da izvan umišljaja i nehata nema niti može biti krivnje. Zbivanja izvan sfere mogućnosti čovjekovog saznanja u konkretnim okolnostima pripadaju sferi objektivne uzročnosti i zakonomjerne slučajnosti. Takva zbivanja pripadaju slučaju (casus). ${ }^{8}$ Kako krivnja kao subjektivna kategorija nalazi svoj puni izraz kroz postojanje umišljaja kao „najizrazitijeg oblika krivice u oblasti krivičnog prava", te kako je upravo umišljaj, i to najčešće direktni umišljaj, zahtijevani oblik krivnje za utvrđivanje da je počinjeno neko vlastoručno krivično djelo od strane službene ili odgovorne osobe, za potrebe ovog rada u nastavku ćemo se zadržati na ovom obliku krivnje, bez detaljnijeg raspravljanja pojma i pojavnih formi nehata.

\subsection{Pojam i elementi umišljaja}

Umišljaj (dolus), promatran kao oblik krivnje, određuje se kao njen redovan i teži oblik, koji sadrži viši stepen prijekora. Krivična djela izvršena s umišljajem uvijek su kažnjiva, dok se krivična djela izvršena iz nehata kažnjavaju izuzetno, kada zakon propisuje takvu mogućnost. KZ FBiH u članu 37. stav 1. najprije propisuje da se krivično djelo može počiniti s direktnim (dolus directus) i eventualnim umišljajem (dolus eventualis), a zatim u stavovima 2. i 3. istog člana definira te dvije vrste umišljaja. Shodno toj definiciji, počinitelj postupa s direktnim umišljajem kada je bio svjestan svog djela i htio njegovo počinjenje, a s eventualnim umišljajem kada je bio svjestan da zbog njegovog činjenja ili nečinjenja može nastupiti zabranjena posljedica, ali je pristao na njeno nastupanje. Lange umišljaj opisuje kao najizrazitiji i najviši oblik krivnje kroz koji se najpotpunije

\footnotetext{
$6 \quad$ Ibid.

7 Tomić, Z., Krivično pravo I, Pravni fakultet Univerziteta u Sarajevu, Sarajevo, 2008., str. 442.

8 Jovanović, Lj., „Pojam i vrste umišljaja“, Zbornik radova Pravnog fakultet u Nišu, br. 16. Niš, 1976., str. 131. - 147.

$9 \quad$ Ibid.
} 
izražava psihički odnos počinitelja prema djelu kao svom ostvarenju, njegov stav prema posljedici kao promjeni na objektu napada koju je on prouzrokovao ili doprinio njenom prouzrokovanju. ${ }^{10}$

Kada je riječ o, kako kaže Lange, psihičkom odnosu počinitelja prema djelu kao svome ostvarenju, tada se taj psihički odnos izražava u svijesti počinitelja o posljedici krivičnog djela i totalitetu stvarnih okolnosti tog krivičnog djela, kao i volji počinitelja da počini krivično djelo. Elementi svijesti nazivaju se intelektualnim elementima umišljaja, a elementi volje voluntarističkim elementima umišljaja. Iz dijela normativnog teksta našeg krivičnog zakona koji tretira intelektualne elemente umišljaja razaznajemo mogućnost da svijest počinitelja bude formirana tako da je relativno siguran da postoje određene okolnosti i da će posljedica nastupiti, ali ta svijest može biti i takva da počinitelj to smatra kao manje ili više moguće. U prvom slučaju je riječ o počinitelju koji je svjestan posljedice odnosno drugih stvarnih okolnosti (drugim riječima, svjestan je svog djela), a u drugom slučaju, počinitelj je svjestan mogućnosti nastupanja posljedice ili drugih stvarnih okolnosti djela, odnosno, kako to KZ FBiH kaže: svjestan je da zbog njegovog činjenja ili nečinjenja može nastupiti zabranjena posljedica. U pogledu voluntarističkog elementa kao ostvarenja htijenja počinitelja krivičnog djela, iz prethodno opisane definicije direktnog i eventualnog umišljaja proizlazi kako počinitelj svoje suglašavanje s ostvarenjem krivičnog djela izražava na način da hoće počinjenje krivičnog djela, što je jači stepen volje zahtijevan za postojanje direktnog umišljaja, a može i samo pristati na izvršenje krivičnog djela, odnosno njegova volja u tom slučaju može biti slabije izražena kroz pristajanje na nastupanje zabranjene posljedice, što je dostatno za određivanje njegovog umišljaja kao eventualnog. U suštini, tamo gdje se intenzitet volje izražava u htijenju imamo direktni umišljaj, a gdje se suglašavanje učinioca izražava u njegovom pristajanju na posljedicu imamo eventualni umišljaj. ${ }^{11}$

Postavlja se pitanje: kada se može reći da je počinitelj krivičnog djela bio svjestan svog djela? Svijest o djelu predstavlja jasnu predodžbu počinitelja o onome što stvarno radi, koja mora obuhvatiti sve bitne okolnosti njegovog čina. Kako se radi o izvršenju krivičnog djela, to predodžba o djelu mora obuhvatiti sve one okolnosti koje su dijelovi zakonskog opisa dotičnog krivičnog djela, a da sam počinitelj ne mora uopće znati koje okolnosti ulaze u zakonski opis nekog krivičnog djela. Svijest o djelu je svijest o svim onim okolnostima danog događaja koje

$10 \quad$ Lange, R., Kohlrausch, E., Strafgesetzbuch mit Erläuterungen und Nebengesetzen. De Gruyter, Berlin, 1956.

11 Srzentić, N., Stajić, A., Lazarević, LJ., Krivično pravo Jugoslavije, opšti deo. Savremena administracija, Beograd, 1995., str. 202. 
ulaze u objektivno biće djela, po kojima će djelo biti kvalificirano; znači, svijest o svim onim dijelovima činjenične situacije koji su i dijelovi zakonske slike danog djela. ${ }^{12}$ Bačić razumijeva svijest o djelu ne samo kao ispravnu predodžbu relevantnih činjenica kao običnih dijelova date situacije, on daje važnu napomenu: da je svijest o djelu podloga da počinitelj može shvatiti i socijalni smisao danog djela, onako kako to odgovara razumijevanju prosječnog građanina. Takva svijest prema Bačiću nije isto što i svijest o protupravnosti djela, koja ne ulazi u sadržaj umišljaja. Tek takvo razumijevanje djela od strane počinitelja odgovarat će i pravnom smislu djela kao cjeline (supsumpcija na laički način). ${ }^{13}$

U kontekstu voluntarističke komponente, volju treba promatrati kao odluku da se djelo ostvari. Takva volja nesporno postoji u svim onim slučajevima kada je radnja sva orijentirana na posljedicu iz bića djela, na ostvarenje zakonskog bića djela, odnosno kada je sva polarizirana prema posljedici. Zakonodavci u $\mathrm{BiH}$ su pojmovima (riječima) "htio“ i „pristao“ odredili ovaj dio umišljaja (direktni i eventualni), dok se u zakonskim opisima različitih modaliteta krivičnih djela počinjenih s umišljajem najčešće koristi pojam namjere („u namjeri da...") Naš zakonodavac pri tome ne daje pojam namjere. Namjera je po ustaljenoj jezičkoj definiciji „ono što je ko odlučio učiniti, zamisao koja će se ostvariti radnjom“. Stoga, ona krivična djela u kojima zakonodavac koristi pojam „u namjeri”, mogu se izvršiti samo s direktnim umišljajem. Promatrano sa suštinske strane, bit voluntarističke komponente se ogleda u htijenju da se povrijedi zaštićeno dobro, koje se ogleda u tome da počinitelj ide upravo za tim da ostvari biće djela, njegovu posljedicu. On postupa prema svojoj ciljnoj predodžbi, u interesu ostvarenja cilja, i tu postoji eksplicitna namjera da se djelo ostvari. Ona je neposredni sastavni dio volje, njen bitni sadržaj. ${ }^{14}$ Međutim, volja se ne mora uvijek izraziti na ovakav način, ona svakako može biti različito strukturirana ovisno o konkretnom slučaju, stepenu htijenja, eksplicitnosti ili implicitnosti volje odnosno namjere. Biće djela može se u tom smislu ostvarivati i kao nužno, sigurno odnosno izvjesno, gdje se rezultat djela ostvaruje kao nužna posljedica samog postupanja. ${ }^{15}$ Praktično su moguće i situacije u kojoj je volja strogo polarizirana, usredotočena na posljedicu bez određene ciljne predodžbe, u kojim se situacijama jasno manifestira samo volja da se djelo ostvari, ali tako da se implicitno iščitava i namjernost činjenja odnosno postupanja.

\footnotetext{
12 Bačić, F., Kazneno pravo, opći dio, Informator, Zagreb, 1998., str. 230.

13 Ibid.

14 Bačić, F., op. cit., str., 234.

15 Npr. osoba A podvrgava osobu B eksperimentalnom tretmanu za kojeg zna da je smrtonosan. Ovdje, i bez namjere, kraj postojanja izvjesnosti o nastupanju posljedice, može se s punom sigurnošću zaključiti o postojanju volje usmjerene na izvršenje djela.
} 


\subsection{Okolnosti normativne prirode. Irelevantnost zablude o supsumciji}

Kada su u pitanju krivična djela kod kojih su počinitelji službene odnosno odgovorne osobe, veoma je važno usmjeriti pažnju na pitanje svijesti o djelu kada je riječ o okolnostima normativne prirode. Kako bi se zauzeo ispravan stav o postojanju umišljaja kod pojedinog počinitelja, njegova svijest mora obuhvatiti tačnu predodžbu o okolnostima koje sačinjavaju datu činjeničnu situaciju, a koje odgovaraju okolnostima zakonskog bića pojedinog krivičnog djela. Ovo podrazumijeva da počinitelj mora biti svjestan punog pravog sadržaja i onih okolnosti koje obuhvataju posebne, npr. stručne, tehničke ili pravne sadržaje, ili neka vrjednovanja (npr. kada su u zakonskom opisu krivičnog djela navedeni pojmovi kao što su isprava, vrijednosni papir, žig i sl.). Predodžbu o ovim okolnostima po prirodi stvari puno je teže percipirati nego predodžbu o pojmovima kao što su stvar, stan, proizvod i sl. Predodžba počinitelja o ovim okolnostima normativne prirode biće ispravna onda ako je počinitelj svjestan smisla i funkcije koje se u realnom, društvenom životu povezuju s takvim okolnostima, odnosno ako je svjestan „na koje je činjenično stanje zakonodavac htio protegnuti krivičnopravnu zaštitu“. ${ }^{16}$ Prema tome, nije uvjet za umišljaj da sam učinilac pravilno interpretira iz zakonskog bića i da pravilno podvede okolnosti svoga ponašanja pod odgovarajuće dijelove zakonskog bića.

Primjera radi, neopravdano bi bilo očekivati da se od odgovorne osobe u pravnoj osobi, za zaključak o umišljajnom ostvarenju krivičnog djela, zahtjeva predodžba o ispravi u smislu juridičke definicije i pojma isprave, kao predmeta podobnog ili određenog da služi kao dokaz neke činjenice, uz svijest o pitanju presumpcije autentičnosti isprave $\mathrm{i} /$ ili drugih pitanja stručne prirode, već je dovoljno da takva odgovorna osoba zna da se uz takav dokument vezuje određena funkcija u svakodnevnom životu, da on služi za dokazivanje, koje znanje onda korespondira s pravnim pojmom isprave. Dakle, kod normativnih obilježja dovoljno je da počinitelj shvati značenje obilježja na laički način, odnosno dovoljna je tzv. „paralelna ocjena u laičkoj sferi“. ${ }^{17}$ Ako odgovorna osoba u neku poslovnu ispravu svoga društva unese neistinit podatak, ona čini krivično djelo Krivotvorenja službene isprave iz člana $389 . \mathrm{KZ} \mathrm{FBiH.} \mathrm{U} \mathrm{slučaju} \mathrm{da} \mathrm{je} \mathrm{počinitelj} \mathrm{iz} \mathrm{prethodnog} \mathrm{primjera}$ svjestan značenja koje predmetni dokument ima u njegovoj svakodnevnici, primjera radi u poslovanju pravnog lica, ali eventualno pogrešno smatra kako se u konkretnom slučaju ne radi o ispravi u smislu zakona, u pitanju je zabluda o supsumpciji koja, u tom slučaju, ne proizvodi nikakve pravne učinke.

\footnotetext{
16 Jescheck, H.-H., Weigend, T., Lehrbuch des Strafrechts, Allgemeiner Teil, Duncker \& Humblot, Berlin, 1996., str. 295.
}

$17 \quad$ Novoselec, P., op. cit., str. 258. 
U tom smislu ilustrativan je primjer iz sudske prakse Okružnog suda u Bjelovaru, u predmetu poslovnog broja Kž-593/86:

„Počinio je k. d. povrede tajnosti pisama i drugih pošiljaka iz čl. 55. st. 1. KZH direktor koji je naložio tajnici da otvori svu poštu koja dolazi na radno mjesto radnika. Nije u pravu okrivljenik kada tvrdi da on nije dao nalog da se otvori tude pismo jer, po njegovom mišljenju, pismo upućeno radniku na adresu poduzeća pripada poduzeću pa da ga on ima pravo otvoriti. Okrivljenik preusko tumači zakonsko obilježje 'tuđe pismo' iz čl. 55. st. 1. KZH i stoga se nalazi u zabludi o supsumpciji koja ne utječe na njegovu krivnju."

O irelevantnosti zablude o supsumciji govori Bačić kada tvrdi da za utvrđivanje svijesti o djelu nije važna subjektivna počiniteljeva interpretacija okolnosti bića djela. Prema Bačiću, nije uvjet za dolus da sam počinitelj ispravno pravno interpretira pojmove iz zakonskog bića te da ispravno podvede okolnosti svog ponašanja pod odgovarajuće dijelove zakonskog bića. O toj se zabludi radi kad neko drži da se određeni činjenični sadržaj ne može podrediti pod određeni zakonski tekst. Zabluda o supsumciji postoji onda kada je počinitelj u vezi sa svojim djelom svjestan određene okolnosti, njezina stvarnog sadržaja, ali je neispravno interpretira. Takva je zabluda irelevantna i u tom slučaju postoji svijest o odnosnom djelu, postoji čista intelektualna komponenta dolusa. To što se počiniteljeva interpretacija razlikuje od korektne zakonske interpretacije ne utječe na postojanje svijesti o djelu. Smisao zakonskog bića ne može biti promijenjen subjektivnom, neadekvatnom počiniteljevom interpretacijom. Zadatak je suca, a ne samog počinitelja, da ono što je za osoba počinila podvede pod odgovarajuće zakonsko biće. ${ }^{18}$

$\mathrm{Na}$ istom je stajalištu i Roxin, koji međutim zastupa mišljenje da se pravna zabluda, tj. zabluda o pravnom vrjednovanju, ne iscrpljuje samo u zabludi o protupravnosti i irelevantnoj zabludi o supsumpciji, već postoje i slučajevi u kojima takva zabluda isključuje umišljaj. Ukoliko se, prema Roxinu, „socijalno značenje određene okolnosti djela može razumjeti [...] bez poznavanja [odgovarajućeg] pravnog koncepta, pogrešne interpretacije prava (pogrešne supsumpcije) namjeru ostavljaju nedirnutom“. Međutim, „tamo gdje pogrešno pravno shvaćanje počinitelja zamagljuje i socijalno značenje djela [...], takva zabluda isključuje namjeru [...]. Namjera je dakle u važećem kaznenom pravu [...] koncipirana kao poznavanje socijalnog značenja, a ne pravne zabrane. "19 Slično rezonira i Puppe

\footnotetext{
18 Bačić, F., op. cit., str. 233.

19 Roxin, C., Strafrecht Allgemeiner Teil Band I: Grundlagen. Der Aufbau der Verbrechenslehre, Verlag C.H. Beck, München, 2006 ..., citirano prema: Martinović, I., Položaj namjere u pojmu kaznenog djela, analiza njezinih oblika i razgraničenje s nehajem, doktorski rad, Pravni fakultet Sveučilišta u Zagrebu, Zagreb, 2013., str. 168.
} 
kada tvrdi da se fokalna tačka zablude sastoji u pitanju razumije li počinitelj smisao pojedine okolnosti koja je od bitnog značenja za biće krivičnog djela. Da bi se npr. stvorila pravilna predodžba o tome da je određena stvar tuđa, nije potrebno poznavanje građanskopravne norme koja regulira šta je to vlasništvo i kako se ono prenosi, već samo to da počinitelj konkretnu stvar smatra tuđom. Sve dok je smisao sačuvan, poznavanje norme nije relevantno, pa se - u slučaju pogrešne predodžbe - ovdje ne radi o zabludi o pravnoj normi, već o zabludi o određenom tipu činjenica. ${ }^{20}$

Kada je riječ o blanketnim obilježjima djela, ona se pozivaju na norme koje ne pripadaju krivičnom pravu, već sadržajno određuju zapovijed ili zabranu koju krivično pravo sankcionira. Budući da pojedini zakonski opisi koji određuju biće krivičnog djela nemaju smisla bez blanketnih normi, one u punom sadržaju pripadaju tom biću djela. U posljednju pak skupinu obilježja bića krivičnog djela spadaju obilježja koja podrazumijevaju cjelovito vrjednovanje djela (gesamttatbewertende Tatmerkmale). Budući da ona pripadaju vrjednovanju, počinitelj ne treba biti svjestan samih tih obilježja, već jedino činjenica na kojima se to vrjednovanje temelji. ${ }^{21}$

\section{Svijest o protupravnosti i umišljaj}

U odredbi člana 35. KZ FBiH koja normira sadržaj krivnje, kao elementi krivnje određeni su uračunljivost i krivnja u užem smislu (umišljaj i nehat), iz čega prozilazi da svijest o protupravnosti nije određena kao element krivnje. $\mathrm{S}$ druge, strane logičkim tumačenjem odredbe člana $37 . \mathrm{KZ} \mathrm{FBIH}^{22}$, pod izrazom „svjestan svog djela“ moglo bi se kazati da se svijest o protupravnosti može supsumirati pod isto, što ga čini zasebnim elementom šireg pojma krivnje. Stoga

$20 \quad$ Puppe, I., Vorsatz und Rechtsirrtum, u: Strafrecht zwischen System und Telos. Festschrift für Rolf Dietrich Herzberg, Mohr Siebeck, Heidelberg, 2008., str. 275.-297.., citirano prema: Martinović, I., Položaj namjere u pojmu kaznenog djela, analiza njezinih oblika i razgraničenje s nehajem, doktorski rad, Pravni fakultet Sveučilišta u Zagrebu, Zagreb, 2013., str. 184.

21 Ibid., citirano prema: Martinović, I., op. cit., str. 186.

22 Član 37. Umišljaj

(1) Krivično se djelo može počiniti s direktnim ili eventualnim umišljajem.

(2) Počinitelj postupa s direktnim umišljajem kada je bio svjestan svog djela i htio njegovo učinjenje.

(3) Počinitelj postupa s eventualnim umišljajem kada je bio svjestan da zbog njegovog činjenja ili nečinjenja može nastupiti zabranjena posljedica, ali je pristao na njeno nastupanje. 
smatramo pogrešnim stav prema kojem se za krivnju zahtijeva svijest o protupravnosti. Za krivnju je dovoljno, kao što je prethodno već napomenuto, da počinitelj krivičnog djela zna za socijalnu odnosno općeprihvaćenu društvenu srž koja predstavlja podlogu pravnih propisa i zabrana. Nije dakle sporno da svijest o protupravnosti predstavlja element krivnje, ali on je zaseban, samostalni element krivnje, izvan umišljaja i nehata, i ne predstavlja njihov dio. Stoga se svijest o protupravnosti ima razmatrati kroz institute stvarne i pravne zablude. ${ }^{23}$

Polazeći od činjenice da su kod delicta propria počinitelji službene ili odgovorne osobe, postavlja se pitanje da li je uopće moguće problematizirati svijest o protupravnosti kao eventualnu negaciju umišljaja kod ovih počinitelja? Odgovor na ovo pitanje potrebno je razmotriti sa dva aspekta. Sa prvoga, službene ili odgovorne osobe moraju poznavati zakonske i podzakonske propise koje primjenjuju u vršenju svojih službenih ili odgovornih dužnosti - eo ipso, ne mogu se primijeniti odredbe stvarne ili pravne zablude, jer „nepoznavanje prava škodi“ (ignorantia iuris nocet), „zabluda o pravu škodi“ (error iuris nocet) odnosno „nepoznavanje prava nikoga ne ispričava“ (ignorantia iuris neminem excusat). S drugog aspekta, sudovi su se u današnjim socijalnim okolnostima našli pred zahtjevom da naprave svojevrstan odmak od ovih starih shvaćanja, te da ponude odgovore na hipertrofiju i specijalizaciju pravne regulative, društvene pokretljivosti i globalizacije, pa je u tom pogledu i sa stajališta načela krivnje upitno kažnjavanje onih počinitelja koji nisu bili svjesni zabranjenosti svog djela, u okolnostima u kojima se opravdano može staviti prigovor da se od istih, uz svu dužnu pažnju i vrhunsko pravno znanje, takva svijest realno nije ni mogla očekivati. Uz uvažavanje svih okolnosti koje prate dinamične društvene promjene, autori ovog teksta su stajališta da je u svakom konkretnom slučaju posebnu pažnju potrebno usmjeriti upravo na pitanje da li je od konkretnog počinitelja moguće zahtijevati takvu svijest. Naime, prema normativnom rješenju našeg pozitivnog zakonodavstva, zabluda o protupravnosti („pravna zabluda“) ne isključuje krivnju, već samo predstavlja fakultativan osnov za blaže kažnjavanje ili oslobađanje od kazne. Stoga je uputno na ovom mjestu navesti sljedeće primjere iz sudske prakse:

„Rješenjima uprave prihoda paušalno je utvrđen porez za 2000. i 2001. godinu, a kao poreske osnovice navedeni su novčani iznosi koji ni približno nisu odgovarali stvarno ostvarenom prometu optuženog. Navedena rješenja su konačna i po njima je optuženi plaćao utvrđene poreze, vjerujući da time ispunjava svoje poreske obaveze. Nije sporno da je optuženi imao odobrenje za rad i na taj način zakonito sticao prihode koji su predmet oporezivanja. Nesumnjivo je da je optuženi u periodu za koji su mu izdata rješenja o paušalnom oporezivanju ostvarivao prihod u

23 Članovi 39. i 40. KZ FBiH. 
iznosima koji su znatno veći od iznosa koji su mu navedeni kao poreska osnovica u rješenjima kojima se utvrđuje porez. Međutim, optuženi je propustom nadležnih poreskih organa održavan u uvjerenju da je plaćanjem poreza u paušalnom iznosu po navedenim rješenjima ispunio u cjelosti svoje poreske obaveze. Na taj način je optuženi bio doveden u pravnu zabludu iz opravdanih razloga jer nije znao da je $i$ pored postojećih rješenja kojima mu je razrezan porez u paušalnom iznosu, dužan da podnese poresku prijavu odnosno sastavi i podnese konačan obračun poreza na promet proizvoda. Dakle, optuženi je imao pogrešnu predstavu o zabranjenosti djela jer je iz opravdanih razloga, zbog već izdatih rješenja o razrezu poreza, smatrao da se podnošenje poreske prijave i konačnog obračuna poreza na promet proizvoda u konkretnom slučaju ne odnosi na njega i nije primjenljivo u konkretnom slučaju. Ovo tim prije što vrijeme izvršenja krivičnog djela zahvata vrijeme važenja složenog pravnog sistema neposredno nakon uspostave Brčko Distrikta BiH. Kako pravna zabluda odnosno nepoznavanje zakon ne izvinjava, to u konkretnom slučaju nepostojanje svijesti o protivpravnosti djela nije isključilo krivičnu odgovornost optuženog za počinjeno djelo. S toga se neosnovano žalbom branioca optuženog ukazuje da nije dokazano postojanje umišljaja kod optuženog. Pitanje krivične odgovornosti optuženog u vrijeme izvršenja krivičnog djela nije dovedeno u pitanje nijednim izvedenim dokazom u toku pretresa pred drugostepenim sudom tako da je, i po ocjeni ovog vijeća, pravilno odlučio drugostepeni sud kada je utvrdio da je optuženi krivično odgovoran za produženo krivično djelo poreske utaje iz člana 272. stav 2. KZ-a FBiH, te ga za isto oglasio krivim, dajući za takvu odluku valjane i logički prihvatljive razloge. "24

U navedenom primjeru, sud je zauzeo stajalište da počinitelj jeste imao pogrešnu predstavu o zabranjenosti djela. Pitanje da li je svrsishodnije ovakvom počinitelju, obzirom na sve okolnosti djela, izreći kaznu ili ga osloboditi kazne, pitanje je koje ne zadire u temu ovog rada. Međutim, s dogmatskog stajališta krivičnopravne nauke, nesporno je da krivnja na njegovoj strani postoji, te da je sud zauzeo stajalište kako su obilježja krivičnog djela obuhvaćena njegovom sviješću i voljom u stupnju zahtijevanom za postojanje umišljaja.

"Optuženi V.K., pak, kao ovlašteno službeno lice Granične policije BiH, morao je imati saznanja o važećim propisima, prema kojima na navedenom graničnom prelazu nije dozvoljen prelazak lica koja ne pripadaju kategoriji lokalnog stanovništva, niti je dozvoljen promet robom. Dakle, i po ocjeni ovog vijeća, van razumne sumnje je dokazano da je optuženi znao da K.P. prevozi robu preko graničnog pre-

24 Presuda Apelacionog suda Brčko Distrikta BiH, broj Kž.124/05 od 25. 08. 2005. godine, dostupna na zvaničnoj web-stranici suda: https://apsud-brckodistriktbih.pravosudje.ba/ vstv/faces/docservlet?p_id_doc=20333 (pristupljeno 11.8.2018. godine). Podvukli autori. 
laza na kojem robni promet nije dozvoljen, te je propuštanjem istog da pređe preko državne granice, kako je to zaključio i drugostepeni sud, pokazao htijenje i namjeru da drugom (K.P.) pribavi određenu imovinsku korist." 25

Stvarna zabluda, odnosno zabluda o biću krivičnog djela i zabluda o okolnostima isključenja protupravnosti negira krivnju (umišljaj), dok pravna zabluda predstavlja okolnost za ublažavanje ili oslobađanje od kazne. Shodno tome, tužilaštva i sudovi prilikom krivičnog progona, odnosno suđenja za službenička vlastoručna krivična djela posebnu pažnju trebaju posvetiti davanju adekvatnog odgovora na pitanje može li službena ili odgovorna osoba biti u neotklonjivoj stvarnoj zabludi, odnosno da li je takvo pitanje questio facti ili je praesumptio iuris, u vezi s propisima koji od ove kategorije počinitelja de iure i de facto zahtijevaju poznavanje propisa i pravilno i zakonito provođenje istih. Ovo je posebno izraženo kod krivičnih djela kod kojih je zaštitni objekt upravo pravilna i zakonita primjena propisa u okviru povjerenih odgovornosti odnosno ovlaštenja. U tom pogledu interesantan je primjer iz sudske prakse Županijskog suda u Puli, koji je u presudi broj Kž-139/00 od 29.4.2002. godine naveo sljedeće:

„Njemački državljanin koji se na području Republike Hrvatske nedopušteno bavi davanjem deviza u zajam i na taj način čini kazneno djelo iz čl. 91. Zakona o osnovama deviznog sustava nalazi se u otklonjivoj zabludi o protupravnosti.“"

U konkretnom slučaju radilo se o njemačkom državljaninu koji se doselio 1990. godine u Umag u R. Hrvatskoj u namjeri da tamo i ostane i koji je svoju njemačku mirovinu koristio za davanje zajmova u njemačkim markama. U kritično vrijeme nije poznavao hrvatski pravni sustav, nije znao hrvatski jezik, ugovore su mu pisali poslovni partneri, tumačila mu ih je supruga, a ovjeravao javni bilježnik. U tim ugovorima stajalo je da se isplata vrši u kunskoj protuvrijednosti njemačke marke, ali su zapravo isplate vršene u njemačkim markama. Općinski sud u Bujama kao prvostepeni sud oglasio ga je krivim zbog krivičnog djela Nedopušteno bavljenje davanjem deviza u zajam iz čl. 91. Zakona o osnovama deviznog sustava, počinjenog u otklonjivoj zabludi o protupravnosti. Županijski sud u Puli kao drugostepeni odbio je žalbu optuženog i potvrdio prvostepenu presudu. ${ }^{26}$

U tom smislu priklanjamo se mišljenju Novoselca koji smatra kako treba poći od načela da se niko ne smije prihvatiti gospodarske djelatnosti, a da se prethodno ne upozna sa svim obavezama koje otud za njega slijede. Poslovni ljudi moraju

25 Presuda Suda Bosne i Hercegovine, broj: S1 2 K 00270211 Kžž od 16. 11. 2011. godine. Citirano prema: Ferhatović, A., "Zloupotreba položaja ili ovlaštenja u zakonodavstvu i praksi”, Godišnjak Pravnog fakulteta u Sarajevu, LIX - 2016, str. 28. Podvukli autori.

26 Novoselec, P., „Sudska praksa”, u: Hrvatski ljetopis za kazneno pravo i praksu, vol. 10, broj 1/2003, Zagreb, 2003., str. 213. 
prostudirati propise kojima se uređuje njihova djelatnost, a u slučaju nedoumice zatražiti mišljenje kompetentne osobe; propuste li to, njihova se zabluda ima smatrati otklonjivom, što će i biti najčešći slučaj. Njemački državljanin koji nije znao da se u Hrvatskoj zajmovi nisu smjeli davati u devizama, pa je stoga počinio kazneno djelo iz čl. 91. Zakona o osnovama deviznog sustava, nalazio se u otklonjivoj zabludi o protupravnosti jer je imao dovoljno vremena i mogućnosti da se raspita o dopuštenosti takve djelatnosti. ${ }^{27}$ Ovakvo mišljenje argumentira stav da počiniteljevo postupanje, ukoliko je počinjeno u dobroj vjeri, može umanjiti njegovu krivnju, ali ne i isključiti ju u potpunosti.

\section{Krivnja kao element krivičnog djela Zloupotrebe položaja ili ovlaštenja}

Zloupotreba položaja ili ovlaštenja, normirana članom 383. KZ FBiH kao i relevantnim odredbama ostalih materijalnopravnih krivičnih propisa u Bosni i Hercegovini, predstavlja genusno djelo službeničkih krivičnih djela koja kao zaštitni objekt postavljaju pravilno i zakonito vršenje službene odnosno odgovorne funkcije. Tumačeći odredbe navedenog člana, jasno je da ovo krivično djelo službena odnosno odgovorna osoba može počiniti samo sa direktnim umišljajem kao oblikom krivnje. Kompleks subjektivnih pretpostavki da bi se jedno protupravno djelo stavilo na teret počinitelju, kao što je ranije istaknuto, mora obuhvatiti sve elemente djela iz člana 383. KZ FBiH. U tom smislu, počinitelj djela mora biti svjestan vlastitog svojstva, radnje i posljedice, kao i biti svjestan da iskorištava svoj službeni položaj, prekoračuje svoje ovlaštenje ili da ne vrši svoju službenu dužnost, kao što i u sferi voluntarističke komponente krivnje mora postojati jasno izraženo htijenje izvršioca da ostvari jednu od posljedica ovog krivičnog djela.

Dokazivanje umišljaja kod ovog krivičnog djela predstavlja vjerovatno najteži zadatak u procesu dokazivanja samog krivičnog djela, budući da se mora van svake razumne sumnje dokazati direktni umišljaj, tj. svijest počinitelja o svim elementima djela kao i njegova volja da se ostvari željena posljedica uz postojanje jasne namjere u tom pravcu, čime se pred nadležna tužilaštva postavlja veoma težak zadatak, jer ovo krivično djelo ima mnogo svojih pojavnih oblika i specifičnosti, pri čemu je često socijalna realnost u kojoj postupaju počinitelji, i značaj subjektivnog odnosa prema ovom djelu unutar takve socijalne realnosti, neopravdano zanemaren.

27 Novoselec, P., „Aktualni problemi hrvatskog gospodarskog kaznenog prava“, Hrvatski ljetopis za kazneno pravo i praksu, vol. 14, broj 2/2007, Zagreb, 2007., str. 390. 
U samom postupku dokazivanja, koriste se sve zakonom određene radnje dokazivanja, i tu nema posebnog pravila niti karakterističnih radnji dokazivanja koje se najčešće primjenjuju. U određenim situacijama, sadržaj različitih isprava ukazuje na umišljaj počinitelja (npr. iz isprava proizlazi očigledno prekoračenje ovlaštenja čega je počinitelj bio svjestan i pri čemu je htio ostvarenje posljedice), dok se u drugim situacijama putem iskaza svjedoka nastoji predočiti sudu jasno manifestirana namjera počinitelja. U dokazivanju umišljaja, tužilac mora posebno ukazati na obavezu službenog ili odgovornog lica da u svakom konkretnom slučaju zakonito i pravilno primjenjuje mjerodavne pozitivne propise s čijim odredbama i pravilima, s obzirom na svoju funkciju, mora biti upoznat i iste mora primjenjivati. Tako npr. odredbe Zakona o privrednim društvima $\mathrm{FBiH}$ propisuju da uprava, odnosno lica koja su osnivačkim aktom ili statutom društva, u skladu sa zakonom, ovlaštena da vode poslovanje društva, zastupaju društvo i odgovaraju za zakonitost poslovanja društva ${ }^{28}$, što se u nastojanju dokazivanja umišljaja mora dovoditi u vezu sa konkretnim događajem. Kada službeno ili odgovorno lice poduzme neki od oblika radnje izvršenja zloupotrebe položaja ili ovlaštenja, tužilac umišljaj dokazuje, pored ostalog, činjenicom da je počinitelj bio svjestan svojih zakonom određenih imperativnih obaveza koje je prekršio, iz čega dalje izvodi i dokazuje namjeru da je upravo tim povredama zakonskih i podzakonskih propisa iskoristio ili prekoračio svoja ovlaštenja u namjeri da ostvari neku od posljedica (korist, štetu ili povredu prava).

Situacija u pogledu dokazivanja umišljaja je znatno teža i kompliciranija kada je riječ o onim modusima zloupotrebe kada službeno ili odgovorno lice formalno ostaje u okvirima svoje službene dužnosti ili ovlaštenja (iskorištava službeni položaj), kada ne vrši formalno povredu određenog propisa, ali ipak u materijalnom smislu postupa suprotno interesima službene dužnosti radi svojih ili interesa drugog. U ovakvim situacijama je dokazivanje umišljaja mnogo teže, jer osumnjičeni, odnosno optuženi svoj koncept odbrane zasniva na tezi da nije povrijedio zakon, da nije prekoračio svoja ovlaštenja, a posebno da nije nastala šteta za drugog. Osumnjičeni se aktivno brane i iznose argumentaciju da nisu bili svjesni protupravnosti svojih radnji ili da nisu imali namjeru bilo kome pribaviti korist ili drugome nanijeti štetu, da je „formalno ispoštovana procedura” odnosno da je „urađeno sve po zakonu”. Iza paravana ovakvih primjera, kojih je u praksi mnogo, najčešće stoje personalni odnosi između počinitelja i pasivnog subjekta koji se mogu kao takvi otkriti i dokazati, osnovom kojih će se onda dokazivati da je počinitelju bio pretežniji interes drugog nego interes službene dužnosti koju obavlja. „Pasivni subjekt" u kontekstu prethodno iznesenog se najčešće odnosi na lice kojem se pribavlja korist, ali koje često nije pasivan u smislu obilježja ovog 
krivičnog djela kao delicta propria, već često ima i može imati svojstvo pomagača ili podstrekača, tj. saučesnika.

Figurativno govoreći, u situacijama u kojima počinitelji krivičnog djela postupaju formalno u okviru svojih ovlaštenja, odnosno strogo formalno promatrano ne postupaju protupravno, postoji formalno uređena fasada iza koje se u materijalnom i faktičkom smislu, krije zloupotreba položaja ili ovlaštenja kojoj se pribjegava kako bi se drugome ili sebi pribavila korist. Olakšavanje procesa dokazivanja umišljaja u takvim slučajevima vidimo u sistematičnom i detaljnom pristupu tužioca koji će svim radnjama dokazivanja (posebnim istražnim radnjama kod kompleksnijih predmeta, kada za to postoje zakonski uvjeti) odstraniti vidljivi sloj te "fasade formalnosti “ $i$ otkriti ono zbiljsko stanje s osvrtom na socijalne implikacije takvog stanja i razumijevanje tih socijalnih implikacija na strani počinitelja krivičnog djela, te posebno obratiti pažnju na međusobne odnose službenog ili odgovornog lica s drugim licima, njihovom neosnovano uvećanje imovine, kao i na sve bitne i pomoćne činjenice i indicije koje mogu ukazati na namjeru počinitelja da drugome ili sebi pribavi korist, a ne da pravilno i savjesno obavlja svoju službenu dužnost. U drugim situacijama, kako bi dokazao umišljaj, tužilac mora dokazivati i prikazivati službene radnje (činjenje ili nečinjenje) službenog ili odgovornog lica u kontekstu obaveze primjene i poštivanja pozitivnih propisa koji se odnose na konkretnu službenu dužnost, pa slijedom toga ukazivati (ne dokazivati) da su službene i odgovorne osobe dužne poznavati (biti svjesni) i primjenjivati pozitivne propise, odnosno u konkretnim predmetima zloupotreba dovoditi u vezu radnje službenih ili odgovornih lica s povredama odnosnih pravnih normi i pravila službe, posljedicama koje su iz toga proizišle, te iz svega toga izvoditi i dokazivati jasnu svijest i namjeru učinioca.

\section{Najčešći problem u dokazivanju umišljaja u predmetima kod kojih su počinitelji službene ili odgovorne osobe iz ugla tužilaštva}

Jedan od osnovnih problema pri dokazivanju umišljaja u ovim predmetima autori prepoznaju u nepravilnom razumijevanju ili pogrešnom prepoznavanju obilježja vlastoručnih službeničkih krivičnih djela. Iako je već prethodno navedeno kako katalog ovih krivičnih djela sadrži nezanemariv broj krivičnih djela s blanketnom dispozicijom, tužilaštvo se često susreće sa poimanjem svakog krivičnog djela protiv službene dužnosti kao a priori blanketnog, čak i u slučajevima gdje povreda blanketnog propisa nije obilježje krivičnog djela. Posljedica navedenog ogleda se $\mathrm{u}$ insistiranju na navođenju ne samo materijalnog propisa suprotno kome je izvršilac postupao, nego i sadržajnom navođenju u čemu se ogleda ta povreda. Ukoliko se radi o krivičnom djelu čija dispozicija upućuje na određeni 
propis, nesporno je da se tužilac mora u opisu radnji izvršenja konkretnog krivičnog djela pravilno pozvati na propise suprotno kojima je počinitelj postupao, tako da optužni akt u svom činjeničnom opisu sadrži sve bitne elemente obilježja bića krivičnog djela. Međutim, ukoliko se ne radi o takvoj vrsti dispozicije, neosnovano je zahtijevati pod svaku cijenu da činjenični opis sadrži i takve podatke, iako isti i bez pozivanja na blanketnu normu sadrži sve potrebne činjenice i okolnosti koje se odnose na radnju izvršenja i ostala bitna obilježja predmetnog krivičnog djela. Ovakvo kategorično insistiranje se kao posebno problematično može odraziti na okolnosti o kojima je bilo prethodno riječ, kada se u radnjama počinitelja ne očituje protupravnost u formalnom smislu, ali su njegovi postupci materijalno protupravni jer nisu poduzeti $u$ interesu službe, već su interesi službe zanemareni i zamijenjeni tuđim interesima.

$\mathrm{U}$ prilog prethodno navedenom, kao argumentaciju navodimo primjer u kojem je Vrhovni sud Federacije $\mathrm{BiH}$, prema shvatanju autora, pravilno ocijenio postupke počinitelja krivičnog djela kao radnju izvršenja krivičnog djela, iako ti postupci u svojoj formalnoj pojavnosti nisu protupravni:

„Budući da je u toku postupka utvrđeno da je optuženi M.M. kao direktor hrvatske filijale S+S M.E.C. Republika Austrija bio ovlašten da u ime kupaca koje bi on pronašao vrši narudžbu robe u navedenoj firmi za te kupce, te da je na osnovu tih njegovih narudžbi skladište vršilo isporuke robe kupcima kojima su uz robu dostavljani i računi, te da je i u konkretnom slučaju pri naručivanju $i$ isporuci robe za preduzeće M., optuženi M.M. formalno postupao u okviru takvih svojih ovlaštenja, ali da konkretne radnje nije preduzeo u interesu službe koju je obavljao nego u sopstvenom interesu, tj. kako bi na opisani način pribavio sebi imovinsku korist, ovaj sud nalazi da je na utvrdeni način optuženi M.M. iskoristio svoja službena ovlaštenja. " ${ }^{29}$

Pored navedenog, čest problem na kojeg nailazi tužilaštvo jeste i striktan formalizam u utvrđivanju svojstva službene ili odgovorne osobe. Svojstvo službene ili odgovorne osobe ne definira se isključivo utvrđivanjem obima prava i obaveza koje proizlaze iz normativnih akata, već je navedeno svojstvo potrebno cijeniti i šire, uzimajući u obzir i ovlaštenja koja je osoba faktično imala. Navedeni stav proizlazi i iz prakse Vrhovnog suda Federacije BiH, iz koje kao ogledni navodimo sljedeći primjer:

29 Presuda Vrhovnog suda FBiH, broj: 070-0-Kžk-06-000023 od 23.05.2007. godine. Citirano prema: Lakić, S., „Problemi u procesuiranju i dokazivanju krivičnog djela Zloupotreba

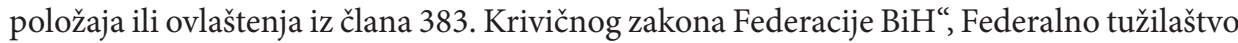
FBiH, 2013., str. 10. Podvukli autori. Sagledavajući prethodni primjer, postavlja se pitanje kako bi tužilac uopće i mogao u činjenični opis uvrstiti povredu blanketnog propisa, kada takve povrede formalno i nije bilo. 
"Prije svega, valja ukazati da među strankama, ni u toku prvostepenog, ni u toku drugostepenog postupka nije bilo sporno da li je optuženi K.T. bio direktor poduzeća P. d.d. Orašje, a time i da je u inkriminiranom periodu, a u smislu čl. 136 st. 5. ranijeg KZ FBiH bio odgovorna osoba. Naime, u konkretnom slučaju odlučna je činjenica to da li je optuženi K.T. u poduzeću Z. d.o.o. Orašje imao svojstvo de facto odgovorne osobe, $u$ isto vrijeme kada je bio direktor de iure $i$ de facto odgovorna osoba u poduzeću P. d.d. Orašje, od čega zavisi i odgovor na pitanje da li je koristeći takav svoj položaj i ovlaštenja kršenjem relevantnih blanketnih propisa pribavio za poduzeće Z. d.o.o. Orašje protupravnu imovinsku korist.

Optuženi je u svojoj odbrani sporio činjenicu da je bio odgovorna osoba, odnosno ovlaštena osoba za zastupanje i predstavljanje u poduzeću Z. d.o.o. Orašje, tvrdeći da je te poslove obavljala njegova supruga. Ovakva odbrana opovrgnuta je nizom dokaza uloženih od strane tužilaštva, iz kojih proizlazi da je optuženi K.T. za poduzeće Z. d.o.o. Orašje de facto obavljao sve poslove odgovorne osobe - slao ponude, sastavljao potrebnu dokumentaciju, pregovarao s drugim pravnim osobama, potpisivao ugovore sa drugim poduzećima, pa se u svojstvu direktora, odnosno, odgovorne osobe tog poduzeća predstavljao i trećim osobama. Prema tome, ovaj sud nalazi utvrdenim da je optuženi K.T. faktički obavljao poslove direktora poduzeća Z. d.o.o. Orašje, dakle, donosio odluke u svojstvu odgovorne osobe tog poduzeća i u tom svojstvu stupao u poslovne odnose sa trećim osobama, što je, osim materijalnim dokazima, potvrdeno i iskazima svjedoka optužbe."30

Svojstvo službene osobe podrazumijeva svojstvo garanta. Stoga bi bilo neosnovano, pored nesporno dokazanih činjenica da je učinilac kao službena ili odgovorna osoba prekršio jedan ili više zakonskih ili podzakonskih propisa ili općih akata, zahtijevati dokazivanje svijesti učinioca tempore criminis o poznavanju istih. Upravo navedeno najeklatantnije ukazuje na poteškoće s kojima se susreće tužilaštvo prilikom dokazivanja umišljaja u predmetima službeničkih krivičnih djela. Radi se o svojevrsnom fenomenu kojeg se usuđujemo nazvati „dvostrukim standardima” u dokazivanju umišljaja. Naime, zaključak o postojanju umišljaja sud izvodi iz svih dokazanih činjenica (neposrednih i posrednih) i okolnosti, ali prije svega iz radnje izvršenja kao vanjske manifestacije svijesti i volje izvršioca. Primjera radi, kod krivičnog djela ubojstva, zaključak o direktnom umišljaju je po pravilu evidentan kada izvršilac pucnjem iz vatrenog oružja iz neposredne blizine liši života drugog; kod krađe kada izvršilac uzme (prisvoji) tuđu pokretnu stvar i sl. Međutim, kod službeničkih krivičnih djela zapaža se insistiranje na dokazivanju dodatnih (viših) unutrašnjih i intelektualnih i voljnih komponenti da

$30 \quad$ Presuda Vrhovnog suda FBiH, broj: $030 \mathrm{~K} 00492812 \mathrm{Kž}$ od 7.11.2013. godine. Citirano prema Ferhatović, A., op. cit., str. 16. Podvukli autori. 
se „drugome ili sebi pribavi korist” u situacijama kada je tužilaštvo dokazalo sve objektivne okolnosti (prije svega radnju) izvršenja iz kojih se može izvesti zaključak o postojanju umišljaja. Situacija u kojoj bi sud propustio pravilno valorizirati radnju izvršenja krivičnog djela (najčešće u kontekstu radnji iskorištavanja, prekoračenja ili nevršenja službene dužnosti kod krivičnog djela Zloupotreba položaja ili ovlaštenja) u korelaciji sa svojstvom izvršioca, posljedicom krivičnog djela i najčešće imperativnim odredbama zakonskih i podzakonskih propisa, iz čije simbioze se može dati pravilna ocjena namjere učinioca, njegove stvarne volje i htijenja, predstavljala bi odstupanje od logične premise da acta exteriora iudicant interiora secreta (vanjske radnje (djela) pokazuju unutrašnju namjeru), što bi, u konačnici, značilo neopravdano nametanje višeg standarda dokazivanja umišljaja pred tužilaštvo, nego što je to slučaj kod ostalih krivičnih djela koja ne spadaju u kategoriju službeničkih krivičnih djela.

\subsection{Primjer dokazivanja umišljaja u predmetu Kantonalnog tužilaštva Un- sko-sanskog kantona}

Kao primjer dokazivanja umišljaja, posebno za pojedince koji se u praktičnom radu susreću sa datom problematikom, autori rada smatraju interesantnim ponuditi slučaj iz predmeta Kantonalnog tužilaštva Unsko-sanskog kantona, broj: T01 0 KTPO 0016891 13. U navedenom predmetu, počiniteljima je stavljeno na teret počinjenje krivičnog djela Oštećenje povjerioca iz člana 246. stav 3. KZ FBiH.

Osumnjičeni H.Ć., H.I. i H.S. optuženi su da su zajedno, u vremenskom periodu od početka januara do kraja juna 2013. godine u Cazinu, kao odgovorna lica Hu. d.o.o., i to H.Ć. kao direktor i suosnivač, a H.I. i H.S. kao suosnivači ovog privrednog društva, svjesni činjenice da je Hu. d.o.o. obavezano na isplatu iznosa od 583.012,00 KM sa zateznom kamatom od 15.08.2007. do isplate povjeriocu BMG. d.o.o. Presudom Općinskog suda u Bihaću br. 170 Ps 01779407 Ps koja je postala pravosnažna presudom Kantonalnog suda u Bihaću br. 170 Ps 01779412 Pž od 03.09.2012, kao članovi Skupštine društva Hu. d.o.o. zajedno i jednoglasno donijeli dana 16. 01. 2013. godine Odluku o smanjenju osnovnog kapitala društva kojom se neosnovano i drastično osnovni kapital Hu. d.o.o. s 3.127.000,00 $\mathrm{KM}$ smanjio na $3.000 \mathrm{KM}$, te $\mathrm{u}$ istom periodu osnovali novo privredno društvo Ho. d.o.o. na istoj adresi kao Hu. d.o.o. s istom djelatnošću i istim osnivačima i direktorom kao i ovo društvo, te svjesni činjenice da je u istom tom periodu povjerilac BMG d.o.o. pokrenuo izvršni postupak pred Općinskim sudom u Cazinu kako bi realiziralo svoje citiranom i izvršnom presudom utvrđeno potraživanje 
na novčanim sredstvima, pokretnim ili nepokretnim stvarima d.o.o. Hu., znajući da su bankovni računi Hu. d.o.o. blokirani i da povjerilac BMG d.o.o. se neće moći naplatiti na novčanim sredstvima dužnika Hu. d.o.o., izvršili prijenos svih pokretnih i nepokretnih stvari sa Hu. d.o.o. na Ho. d.o.o. s ciljem da osujete realizaciju potraživanja i izigraju povjerioca BMG d.o.o., pa su tako dana 17. 05. 2013. godine izvršili prijenos vlasništva svih pokretnih stvari - raznih vozila i mašina sa Hu. d.o.o. na Ho. d.o.o. kako bi preduhitrili povjerioca BMG d.o.o. u namjeri da se izvrši zabilježba izvršenja na ovim stvarima i dana 22. 05. 2013. godine izvršili prijenos prava vlasništva nad svim nekretninama vlasništva Hu. d.o.o. ugovorima o kupoprodaji u vlasništvo Ho. d.o.o. gdje su predmetne nekretnine iz ovih ugovora prodali Ho. d.o.o. po ukupnoj cijeni od 442.000,00 KM iako je procijenjena vrijednost istih bila 1.764.509,00 KM čega su i sami bili svjesni, kojim radnjama su učinili Hu. d.o.o. nelikvidnim i nesolventnim znajući da će ove radnje prijenosa imovine na Ho. d.o.o. koje nije bilo pravni sukcesor Hu. d.o.o. onemogućiti povjerioca BMG d.o.o. da naplati svoje potraživanje iz imovine $\mathrm{Hu}$. d.o.o., čime su oštetili BMG d.o.o. za iznos od 583.012,00 KM s pripadajućim kamatama.

Istovremeno, Hu. d.o.o. kao pravno lice optuženo je da je u vremenskom periodu od početka januara do kraja juna 2013. godine u Cazinu, Odlukom Skupštine društva o smanjenju osnovnog kapitala društva od 16. 01. 2013. godine koju su jednoglasno donijeli njegovi članovi Skupštine i odgovorna lica H.Ć., H.I. i H.S., s ciljem da onemogući naplatu potraživanja povjerioca BMG d.o.o. u iznosu od 583.012,00 KM sa zateznom kamatom od 15.08.2007. do isplate utvrđeno Presudom Općinskog suda u Bihaću br. 170 Ps 01779407 Ps koja je postala pravosnažna presudom Kantonalnog suda u Bihaću br. 170 Ps 01779412 Pž od 03.09.2012, neosnovano i drastično smanjilo svoj osnovni kapital s 3.127.000,00 KM na 3.000 $\mathrm{KM}$, te izvršilo prijenos svih pokretnih i nepokretnih stvari na Ho. d.o.o , pa je tako dana 17. 05. 2013. godine izvršilo prijenos vlasništva svih pokretnih stvari - raznih vozila i mašina koja čine njegova osnovna sredstva na Ho. d.o.o. i dana 22.05.2013. godine izvršilo prijenos prava vlasništva nad svim nekretninama u svom vlasništvu ugovorima o kupoprodaji u vlasništvo Ho. d.o.o. gdje je predmetne nekretnine iz ovih ugovora prodalo Ho. d.o.o. po ukupnoj cijeni od 442.000,00 KM iako je procijenjena vrijednost istih bila 1.764.509,00 KM, te na takav način povjeriocu BMG d.o.o. onemogućilo naplatu potraživanja, čime je nanijelo štetu svom povjeritelju BMG d.o.o. u iznosu od 583.012,00 KM s pripadajućom zateznom kamatom.

$\mathrm{U}$ toku istrage, Tužilaštvo je izvršilo pretresanje službenih prostora Hu. d.o.o., kojom prilikom je izvršeno i privremeno oduzimanje financijske dokumentacije navedenog društva. Poduzet je i uviđaj na licu mjesta, te je sačinjena fotodoku- 
mentacija s akcentom na grafički identitet (logotip) starog (Hu. d.o.o.) i novog društva (Ho. d.o.o.) na istoj adresi. U svojstvu svjedoka saslušan je oštećeni, zakonski zastupnik BMG d.o.o., te je pribavljena i ostala relevantna dokumentacija, posebno odluke Skupštine društva o smanjenju osnovnog kapitala društva. Na osnovu navedenog izvršena je komparativna analiza iste, sačinjavanjem prikaza komparativnih radnji optuženih u vezi s pokretanjem izvršnog postupka u predmetu Općinskog suda u Cazinu broj 200 Ip 02426913 Ip tražitelja izvršenja BMG d.o.o. protiv izvršenika Hu. d.o.o. Provedeno je financijsko vještačenje opravdanosti Pisanog izvještaja o smanjenju osnovnog kapitala od 11. 1. 2013. godine, kao i smanjenja osnovnog kapitala društva sa 3.000.000 KM na 3.000 $\mathrm{KM}$, analiza bruto bilansa društva za prethodne dvije poslove godine i utvrđenje činjenice solventnosti društva i financijske mogućnosti ispunjenja obaveza prema povjeriocima tempore i ante delictum. Izvršena je komparativna analiza svih dokaza, s ciljem dokazivanja radnji optuženih koje su se odvijale vremenski paralelno odnosno istovremeno sa radnjama oštećenog koji je pokušavao putem izvršenog postupka prinudno realizirati svoje pravosnažnom presudom utvrđeno potraživanje. Rezultat provedenih istražnih radnji je jasno i očito postojanje umišljaja optuženih u vidu radnji izbjegavanja ispunjenja obaveze prema povjeriocu.

\section{Zaključak}

Dokazivanje umišljaja, po pravilu direktnog, kao zahtijevanog oblika krivnje kod počinitelja krivičnih djela koja potpadaju pod službeničkih, nerijetko je povezano s izrazitim teškoćama. Pored toga što su ove poteškoće uvjetovane kompleksnošću socijalnih interakcija aktera ovih krivičnih djela i specifičnostima karakterističnim za događaje u stvarnosti u okviru kojih se ostvaruju navedena krivična djela, dileme često proizlaze iz neadekvatnog razumijevanja ukupnosti pravnog supstrata navedenog instituta. Prilikom krivičnog progona i procesuiranja počinitelja ovih krivičnih djela, pred tužilaštva i sudove postavljen je zahtjevan zadatak prepoznavanja njihovih bitnih obilježja u sferi pojavnosti konkretnih događaja koji se odlikuje kompleksnošću interakcija učesnika, njihovih svojstava, uključujući kao možda i najzahtjevniji ali ujedno i najvažniji zadatak prepoznavanje subjektivnog, psihičkog odnosa počinitelja prema ostvarenju djela odnosno prema posljedici koja nastupa. Upravo razlozi delikatnosti navedenih krivičnih djela, ali i više od toga, specifične, veoma izražene negativne posljedice koje ova društveno neprihvatljiva ponašanja ostavljaju u socijalnom konstruktu društva, zahtijevaju iznalaženje adekvatnih rješenja za pravilno razumijevanje 
odnosa počinitelja prema ovim krivičnim djelima kao pravne kategorije, ali takve kategorije koja neumitno mora biti prožeta razumijevanjem svih okolnosti u ukupnosti njihovog socijalnog značaja. Tek ovakvo shvatanje umišljaja, uz uvažavanje razrađenih doktrinarnih postulata krivičnopravne nauke, može rezultirati adekvatnim formiranjem formalno, materijalno i logično pravilnih vrijednosnih sudova o psihičkom, subjektivnom odnosu počiniteljâ krivičnih djela prema onome što je objektivno eksteriorizirano vanjskim manifestacijama njihovih radnji i posljedicama koje su te radnje prouzrokovale.

\title{
PROVING INTENT IN CRIMINAL OFFENSES COMMITED BY OFFICIAL OR RESPONSIBLE PERSONS
}

\begin{abstract}
Summary: Understanding and proving the psychic relationship of perpetrators of criminal offenses, in which the perpetrators appear as official or responsible persons, is primarily for the prosecution, probably the biggest challenge. Intent, as the focal point of the criminal law system, in a reality in which prosecution of perpetrators of this type of crimes is indisputably a task of exceptional significance in social terms as well as in regards to criminal policy, is an institute that is distingiuished by its characteristic. Therefore it is necessary to devote considerable attention to the question of proofing intent. It is crucial to perceive this institute in a way that is based on criminal law doctrine, in order to avoid any form of arbitrariness of process entities, and in order to fully accomplish the purpose of criminal prosecution and sanctioning by correct understanding of the given form of guilt. In this regard, it is necessary to highlight some of the dilemmas that arise when assessing the existence of intent on the side of perpetrators of the aforementioned crimes. In this paper, the authors offer a review of essential doctrinal notions of intent within the framework of domestic and foreign criminal law dogmatics, presenting general observations about the institute. At the same time, the authors are emphasizing the necessity of making a distinction between intent, and other institutes of criminal law such as error about subsumption, awareness of unlawfulness, real and legal errors, along with providing practical case-law examples that support the argumentation presented in the paper. In addition to the above, authors provide a review on intent as element of the crime of abuse of official duty or authority as the basic criminal offense in regard to this type of criminal offenses. In the end, authors present the most frequent problems that arise in the process of proving intent from the aspect of the prosecution, discussing potential ways of overcoming these problems, based on their own view.
\end{abstract}

Keywords: criminal offense, intent, dolus, guilt, official person, responsible person 